\title{
TAX IMPLICATIONS OF DIVIDEND POLICY
}

\author{
ZOLTÁN BARABÁS ${ }^{1}-$ GERGELY FAZAKAS ${ }^{2}$
}

\begin{abstract}
This study examines the tax-arbitrage possibilities on the Budapest Stock Exchange between 1995 and 2007. The theoretical possibility for the arbitrage is the different taxation for different stockholders, for the private investors and for the institutions: the institutions had higher taxation on capital gain while private persons in the whole period had tax-benefits on capital gains. The dynamic clientele model shows, that there is a range of the price drops after dividend payouts which guarantees a risk-free profit for both parties. The research is based on the turnover data from 97 companies listed on the Budapest Stock Exchange. We have tested the significant turnovers around the dividend-dates. The study presents clear evidence that investors continuously did take advantages on the different taxation.
\end{abstract}

KEYWORDS dividend policy, tax implications, tax-arbitrage, dynamic clientele

The focus of debates about dividend policy is whether any given extent of dividend pay-out creates added value for shareholders - i.e., whether any price change is induced by such alterations of the dividend level that are announced currently or expected in the future. At the most basic level, the main problem concerning dividend policy is whether to pay out profits as dividends or to plow the money back into the company as reinvestment. It seems that several factors influence firms' dividend policy: risk, taxes, costs, information, shareholders, clienteles, shareholders' behavior etc. We will only deal with the tax effects.

1 Zoltán Barabás is a fifth-year student at Corvinus University of Budapest

2 Gergely Fazakas is Associate Professor at Corvinus University of Budapest, Department of Investment and Corporate Finance; e-mail: fazakasger@t-online.hu 
Modigliani and Miller's famous model is a key point in these debates. The model did not rely on actual practice, but was built upon a purely theoretical set of conditions, assuming perfect capital markets and rational investors. ${ }^{3}$

The key conclusion of the model was that investors' attitude toward dividend policy is indifferent as regards the generation of shareholder value; they saw no difference between getting their earnings through the profitable operations of the company via dividend pay-outs or from increased prices after earnings are plowed back into the company.

From the late 1960s, a new school emerged which actually brought the minimization of the dividend into the foreground, the so-called radical left wing. Their argumentation focused on the different rates of capital gains taxes and taxes on dividends. In the United States, tax was imposed on dividends in a similar way as to the Hungarian personal income tax consolidated tax base, and only capital gains tax was thought of as being related to separate incomes. Due to this fact, dividends were taxed progressively along with the investor's other income streams, including wages and salaries from labor relations. On the other hand, the majority of the various progressive tax rates, which naturally applied to a great extent to those who had the largest incomes, and therefore were capable of investing - exceeded the effective rate of capital gains tax, meaning that incomes received as dividends were prejudiced against from a tax perspective. The point of the radical dividend-cutting position was that, as long as the owners of the company paid more taxes on dividends than on capital gains, any dividend pay-out meant losses of assets for shareholders to the extent which corresponded to the actual tax disadvantages. Therefore, it seemed expedient to minimize dividend payments, or defer them to optimal cases, and furthermore to eliminate them fully in extreme cases, and to completely re-orient shareholders towards preferring cash withdrawals through selling their shares.

3 Assumptions regarding the perfect market: there is no taxation or governmental intervention, all the actors accept the prices, there are no monopolistic or oligopolistic positions, there is free entrance and exit in relation to markets and perfect access to information, i.e., the market efficiently functions. Investor rationality means that maximization of investor utility involves the maximization of assets and minimization of risks. The model and its consequences can be seen in more detail in Jaksity [1991]. 


\section{CLIENTELE MODELS ESTABLISHED ON THE BASIS OF TAX IMPLICATIONS}

Models relying on tax implications can be divided into two main groups:

- models relying solely on tax implications;

- models examining the combined effects of taxes and other factors (risk, information etc.).

This part focuses exclusively on the first group. Models relying on tax implications are excellently categorized in the study by Judit Kosárka [2007], and thus most of this chapter makes use of her work, which represents an extensive resource.

According to related literature, a situation clientele model is one which, on the basis of various preferences, investors opt for different companies, and thus companies see the emergence of their own steady clienteles and circles of investors.

The grouping options of clientele models established on the basis of tax implications are shown in Figure 1.

Figure 1 Models for examination of tax implications on dividend policy

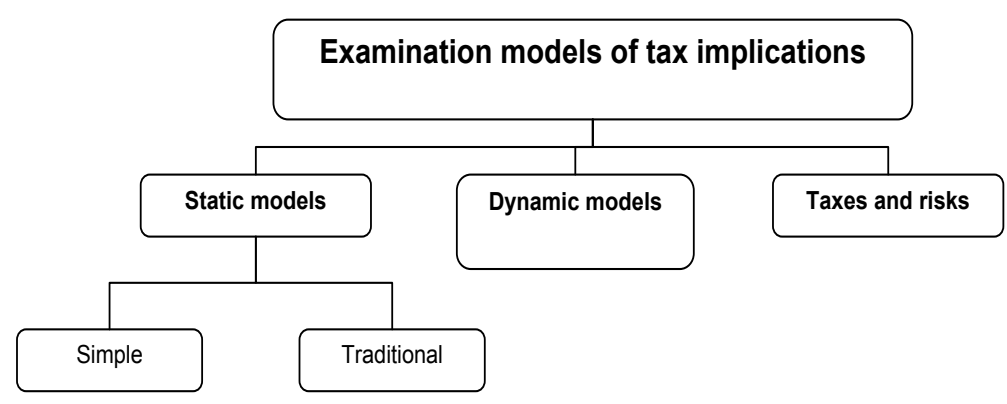

Source: Fazakas \& Kosárka [2008]

\subsection{Static models}

Static models analyze the influences within a given investment environment - how investors can adapt themselves to given tax rates with any specific corporate dividend policy, and how this is reflected in share prices. The static investor strategy means that with an unchanged dividend policy in equilibrium, investors do not trade their securities, but maintain their positions. (Brennan [1970], Litzenberger \& Ramaswamy [1980], [1982]) 


\subsubsection{Simple static clientele models}

A fundamental assumption of simple static models is that investors pay taxes on the basis of the same tax rate - both the rate of capital gains tax and the tax on dividends are identical for all stakeholders, but the tax rate on dividends are higher than the rate of capital gains tax for all investors. This is similar to the actual taxation situation in the United States where the tax rate on dividends tends to be larger. These models also suggest that shares with large dividend yields promise large, predictable after-tax earnings, and therefore represent greater value than shares paying smaller dividends which have higher growth rates.

\subsubsection{Traditional clientele models}

In traditional clientele models, the marginal incomes of investors fall under various tax rate ranges, and therefore these investors have different dividend preferences. The relative tax advantage for investors with higher tax rates leads to a shift in payment demands towards capital gains, whereas the relative tax benefit for investors with lower-income tax rates leads to calls for dividend payouts.

The way the tax rates of investors determine the after-tax value of the dividends of shares they acquire is hereby demonstrated on the basis of an Elton and Gruber publication (Elton \& Gruber [1970]). In this classic model, investors are risk-neutral and their main objective is the maximization of their after-tax assets. Within the context of the model, there is an equilibrium situation when the investor is indifferent to acquiring a given share before or after dividend payment. In other words, this means that whether dividend payment or profit gain is opted for, the after-tax cash flow realized will be the same.

The essence of the model is that, upon dividend payment, the expected drop in share price is less than the actual volume of the dividend; i.e., the decrease of the price in relation to the paid dividend reflects the relative tax disadvantages of dividends.

In the test performed by Elton and Gruber [1970], they examined to what extent the dividend yields of shares and the dividend payout ratio determine the scope of owners of shares. In their hypotheses, investors with higher tax rates would choose securities with small dividend payouts, while investors with lower tax rates would prefer securities with large dividend yields in order to realize their respective tax benefits. Their studies succeeded in confirming the 
hypothesis that there is a strong negative relationship between the clientele's share tax rate range and their share dividend payout. The results of subsequent empirical tests have been largely the same: Blume et al. [1974] , Long [1977], Allen and Michaely [2002], and Graham \& Kumar [2005] carried out research on the basis of US samples; Dahlquist et al. [2007] in Sweden strengthened the hypotheses of the model by finding a systematic relationship between the structuring of individual portfolios and share dividend yields.

In the static model there is no regular trading - this model is relevant when the transaction costs of trading are excessively large, and therefore the benefits of tax minimization to be realized by means of multiple trading (that is, a dynamic strategy) are overruled by the associated disadvantages. To evade the tax disadvantages of dividends, the simplest recipe offered by the static model is for investors with marginal tax rates greater than their capital gains tax rate to refrain from holding dividend-paying shares.

\subsection{Dynamic models}

The assumption underlying dynamic models is that investors do not take their optimal positions statically, but rather maximize the taxed value of these positions by means of continuous trading. In the static model, investors react only to changes in the investment environment (taxation, dividend policy, other new information), seek new equilibrium, and maintain their positions until there is another change in determinant factors. In contrast, investors in dynamic models follow a strategy that generates trading even without changes in the dividend policy of the company or the taxation environment.

The essence of dynamic strategies developed in view of tax implications is that at the time of dividend payment, investors implement such a trading strategy where their after-tax earnings are maximized. Stakeholders incurring a disadvantageous tax situation with respect to dividends will sell their securities to those who pay taxes on dividends at a more favorable rate, or at least the same rate, as with capital gains. After dividend payment, reverse transactions are also concluded, meaning that both groups of actors will hold those volumes and positions they had initially targeted in the long run.

A forerunner of the modeling of this dynamic strategy was Kalay [1982]. In his model, if a perfect market is assumed (or to be more precise, if market imperfections are embodied only in the form of taxes), i.e., there are no transaction costs, access to information is perfect, and no institutional contracts

4 Cited by Allen \& Michaely [2002] 
for trading exist, then through trading investors can fully eliminate the tax disadvantages of the tax on dividends. In this approach, as trading associated with dividend payment is limited to just a few days, no considerable time risks arise, and the given situation in fact turns into arbitrage. In this context, it is perfect arbitrage options that ensure that the drop in the ex-dividend price should correspond to the actual volume of the dividend, but cannot be smaller.

Kalay [1982] claimed that conventional (i.e. static) dividend-based clientele models were non-existent, because at the time of dividend payment, investors relied on arbitrage activities to get rid of their tax payment obligations on dividends. It has been observed through a number of studies of capital markets throughout the world - for instance, in the United States, Italy, Japan, Sweden, and Norway - that significant turnover occurs at dividend payment time. This turnover positively correlates with the amounts of dividends paid, but negatively correlates with transaction costs and the risks of the interim period.

\subsubsection{Empirical tests of dynamic trading}

In opposition to the statements of Kalay [1982], a number of publications have questioned the efficiency of arbitrage trading. Elton \& Gruber [1970], Poterba \& Summers [1984] , and even Kalay [1982] observed that price drops due to dividend payments were smaller than the volumes of the associated dividends, meaning that the arbitrage effectuated in order to eliminate the disadvantages of the tax on dividend did not function perfectly. Michaely \& Vila $[1995]^{6}$ found that at dividend payment time only a very small proportion of shares - in general less than $1 \%$ of the outstanding shares - were transferred, and furthermore, some of these transactions took place within the same tax group. (Allen \& Michaely [2002]).

In practice, the occurrence of complete arbitrage is hindered by the existence of transaction costs as well. Kalay thought that investors effectuate arbitrage as long as it is worth it for them in view of given transaction costs. In his opinion, price decreases due to dividend payments (as well as their ratios in relation to dividend per share) primarily reflect the differences between tax benefits and transaction costs which prevent further trading, and not purely

5 Cited by Allen \& Michaely [2002]

6 Cited by Allen \& Michaely [2002]

CORVINUS JOURNAL OF SOCIOLOGY AND SOCIAL POLICY 2 (2010) 
dividend tax rates. Others have come to similar conclusions; tests conducted by Michaely \& Vila [1996] and Michaely et. al. [1997] confirmed that volumes associated with the dynamic trading strategy decreased in number as a result of transaction costs and increased risks.

Dynamic tax minimization models have a number of practical consequences, and the associated effects can as also be perceived in Hungary, for example, around dividend payment timing for shares carrying large dividend yields.

\subsubsection{Theoretical framework of the model}

The model explained by Kalay [1982] has substantial practical consequences. The model concerns dynamic tax minimization, meaning that at dividend payment time, investors in various tax brackets are able to effectuate tax arbitrage by means of trading activities. The associated effects can be perceived, e.g., in Hungary, at dividend payment time, on shares with considerable dividend yields. For this reason, this theory is explained in detail.

Hereunder, tax arbitrage is defined as a type of share trading activity executed for the purpose of reducing the aggregate tax payment obligation (sum of the tax on dividend and capital gains tax) of the participants. As a result of the arbitrage, all participating actors typically see their tax payment obligations reduced, yet within the context of the model it is sufficient to assume that the obligations of at least one stakeholder decrease, while none of the actors are subject to increased payable taxes.

Kalay's conclusion is based on the fact that there are no obstacles to arbitrage - for instance, trading is not hindered by capacity (position) problems. Arbitrage occurs due to the fact that there are at least two groups of investors whose circumstances differ regarding taxes on dividends. ${ }^{8}$ Let's firstly assume that investors are indifferent as to how these rates are related to the volume of the capital gains tax. The first group may be termed $\mathrm{H}(\mathrm{H}$ as in 'high' for high tax rates), and the other $\mathrm{L}$ ( $\mathrm{L}$ as in 'low' for low tax rates). The associated indications are:

$T_{D H}$ - rate of the tax on dividend for those with large incomes,

$T_{D L}$-rate of the tax on dividend for those with small incomes,

7 Cited by Allen \& Michaely [2002]

8 Kalay assumes the presence of private persons in both investor groups with their capital gain taxes are identical. If capital gain taxes are different, then for arbitrage it is also necessary to have a different ratio of tax rate on dividend to rate of capital gains tax in the two groups. 
$T_{p g}$ - rate of the capital gains tax,

$P_{A}$ - price before dividend payment (cum-dividend price),

$P_{B}-$ ex-dividend price,

$D I V$ - dividend per share,

and $T_{D L}<T_{D H}$.

The volume of the after-tax dividend for group $\mathrm{H}$ is $D I V^{*}\left(1-T_{D H}\right)$, and for group $\mathrm{L}$ is $D I V^{*}\left(1-T_{D L}\right)$. It is compensated for by a drop in the share price, which therefore equates to tax savings on the capital gains tax. For the two distinct groups, the general form of the price decrease that makes participants indifferent to trading, or in other words, functions as the equivalent of the dividend profit gain, is:

$$
\left(P_{B}-P_{A}\right)=D I V * \frac{1-T_{D}}{1-T_{p g}}
$$

Equation (1) can be applied to group $\mathrm{L}$ and $\mathrm{H}$ accordingly, with the following conversions:

$$
\begin{aligned}
& \text { Group L: }\left(P_{B}-P_{A}\right)_{L}=D I V * \frac{1-T_{D L}}{1-T_{p g}} \\
& \text { Group H: }\left(P_{B}-P_{A}\right)_{H}=D I V * \frac{1-T_{D H}}{1-T_{p g}}
\end{aligned}
$$

As $T_{D L}<T_{D H}$, thus $\left(P_{B}-P_{A}\right)_{L}>\left(P_{B}-P_{A}\right)_{H}$

If there were only $\mathrm{H}$ investors with high tax rates, the market price would drop to a smaller extent in comparison with the situation where solely L investors with low tax rates existed. For instance, if the share price is 1,000 and the dividend per share is 100 , and $\mathrm{H}$ and $\mathrm{L}$ tax rates on dividends are $20 \%$ and $10 \%$ respectively, while the capital gains tax rate is $10 \%$, then the arbitrage-neutral position for $\mathrm{H}$ would cause a drop in price of $88.8(100 * 0.8 / 0.9)$, and a drop of 100 for $\mathrm{L}(100 * 0.9 / 0.9)$. Therefore, $\mathrm{H}$ investors target an ex-dividend price of 911.1, whereas L investors prefer 900. For investor L, it is a good bargain to purchase the share before dividend payment, and thereafter sell it between 900 and 911.1, whereas $\mathrm{H}$ would prefer to sell it prior to dividend payment, and repurchase the share in the same price range after dividend payout.

Consequently, for both groups, an arbitrage option arises to the extent of a decrease in price of somewhere between $\left(P_{B}-P_{A}\right)_{L}$ and $\left(P_{B}-P_{A}\right)_{H}$. As long as at least one of the groups realizes its fully intended position (all $\mathrm{H}$ investors sell their securities, or all L investors purchase the largest possible volume), 
the arbitrage situation survives. The actual extent of the price drop within the given price decrease range depends on the mutually-related trading volumes of the two groups. If the capacity of the L actors is stronger, they will cause the cum-dividend purchase prices to rise sharply, while bringing down the selling prices after the dividend payment, and therefore the decrease in price will approximate the $\left(P_{B}-P_{A}\right)_{L}$ value regarded to be the limit value for them (this is what Kalay suggests in the model).

Using the figures in the above example, the last $\mathrm{L}$ investor, for example, may pay 1,005 for the share with the dividend coupon, and sell for 906 without the dividend coupon. In this case, their profit gain is -99 , with its (negative) tax, i.e., the reimbursable amount of tax or tax savings is +9.9 . The value of the dividend they receive is 100 , and the tax on the dividend is 10 . The total earning of the $\mathrm{L}$ investor is therefore +0.9 .

Investor $\mathrm{H}$ realizes a profit gain of 99 , whose tax is -9.9 . At the same time, he does not collect the dividend of 100, which would only be worth 80 after the tax payment, meaning that on the whole his position improves by 9.1 . In the opposite case, group $\mathrm{H}$ would like to enforce their will against the other group, and for this reason they push down the price before dividend payment due to selling pressure, while increasing the ex-dividend price through purchasing pressure, and therefore the price drop approximates value $\left(P_{B}-P_{A}\right)_{H}$, deemed to be their limit value. If both groups have retained unsatisfied capacity, or transaction costs hinder the exploitation of arbitrage opportunities, the price drop can fall anywhere within the range. What is constant is the joint profit of the two groups (and the loss for the state), which amounts to a difference in price which is still acceptable for the two actors - being taxed with the combined tax rate of capital gains thus:

$$
\left(D I V * \frac{1-T_{D L}}{1-T_{p g}}-D I V * \frac{1-T_{D H}}{1-T_{p g}}\right) *\left(1-T_{p g}\right)=D I V^{*}\left(T_{D H^{-}} T_{D L}\right)
$$

With the use of the figures in the above example, the result of the jointly achievable arbitrage in conformance with (4) is:

$$
(100 * 0.9 / 0.9-100 * 0.8 / 0.9) * 0.9=100 *(0.9-0.8)=10
$$

The final conclusion of Kalay's above-mentioned theory, i.e., that actors are able to evade the tax on dividend entirely, is true only when investors with high tax rates can all close their positions prior to dividend payment - 
meaning that investors with low tax rates can absorb all those securities from the market that are still available for sale before dividend payment.

If there are more than two groups, arbitrage options are available in the broadest possible range for actors with the highest tax rates. The arbitrage option is also available to investors with middling tax rates, but it is not obvious to them whether they should long or short the security: it depends on the price range within which the trading activities of the two extreme (and other) groups move. According to Kalay's assumption, the combined outcome is tax savings, but not all groups can save on their taxes on dividend even if the tax rate on dividend exceeds the capital gains tax rate for all of them. It may be more profitable for them to "take over" the tax on dividend imposed on actors with high tax rates in consideration of the expected larger capital gain (i.e., a smaller price drop). Again, the market becomes fully clarified if investors with the lowest tax rates are able to acquire the shares sold by all the other groups with higher tax rates prior to dividend payment.

The extent of exploitable tax arbitrage is drastically increased if institutional investors are also involved in activities. In most of the capital markets, corporate investors are taxed under different principles in comparison with private actors: for dividends received from other companies, corporate investors are generally granted tax benefits (such as in the United States and Germany), and furthermore, sometimes benefit from complete exemption from tax (Hungary). Consequently, Pareto's optimal price range further opens.

\section{THE MODEL OF DYNAMIC TAX MINIMIZATION IN PRACTICE}

\subsection{The possibility of dynamic tax minimization in Hungary}

As regards the Hungarian investment climate, only two types of clienteles can be distinguished: corporate and private person investors. Private persons pay taxes on dividends and income from capital gains as separate income. The only potential difference that can be detected when the incomes of private persons are observed is that under certain conditions (capital account, company listed on the stock exchange) they are liable to pay taxes at a more favorable tax rate or in the case of dividends exceeding $30 \%$ of adjusted equity, the payable taxes are (were) calculated at a more unfavorable dividend tax rate. Regarding companies listed on the stock exchange, for which the payment of dividends over the above limit ( $30 \%$ of the adjusted equity) to effectuate the 
$35 \%$ rate does not occur. By holding shares listed on the stock, two groups of private persons have been specified: investors with "normal rates" and those with preferential tax rates. (See Table 1.)

Tax rates show substantial differences, which tempt various investors to dynamically minimize their tax burdens. To measure the potential extent of tax minimization, the first step should be the application of formula (1), defined as the equivalent of the gain on dividend:

$$
\left(P_{B}-P_{A}\right)=D I V * \frac{1-T_{D}}{1-T_{p g}}
$$

By rearranging the equation, the ratio of tax implications can express a price in the equivalent of a USD 100 dividend for a given investor, i.e., what the equivalent of the gain on dividend is.

$$
\begin{gathered}
\left(P_{B}-P_{A}\right) / \mathrm{DIV}=\frac{1-T_{D}}{1-T_{p g}} \\
\mathrm{~T}^{*}=100 * \frac{1-T_{D}}{1-T_{p g}}
\end{gathered}
$$

wherein

$T_{D}-$ tax rate on dividend,

$T_{p g}$ - rate of capital gains tax,

$T^{p k}$ - volume of the capital gain which ensures the same after-tax profit as 100 units of dividend (the equivalent of 100 units of gain on dividend). 
Table 1 Tax rates of private persons and companies on dividend incomes and capital gains, 1990-2010

\begin{tabular}{|c|c|c|c|c|c|c|}
\hline & \multicolumn{4}{|c|}{ Private person } & \multicolumn{2}{|c|}{ Company } \\
\hline & \multicolumn{2}{|c|}{ Capital gains tax } & \multicolumn{2}{|c|}{ Tax on dividend } & \multirow{2}{*}{$\begin{array}{c}\begin{array}{c}\text { Capital } \\
\text { gains }\end{array} \\
\operatorname{tax}^{2} \\
\end{array}$} & \multirow{2}{*}{$\frac{\text { Tax on }}{\text { dividend }}$} \\
\hline & Normal & $\begin{array}{c}\text { Capital } \\
\text { account }\end{array}$ & Normal $^{1}$ & $\begin{array}{c}\text { Listed } \\
\text { company }\end{array}$ & & \\
\hline 1990 & $20 \%$ & $20 \%$ & $20 \%$ & $20 \%$ & $35 \%$ & $35 \%$ \\
\hline 1991 & $20 \%$ & $20 \%$ & $20 \%$ & $20 \%$ & $35 \%$ & $35 \%$ \\
\hline 1992 & $20 \%$ & $20 \%$ & $10 \%$ & $10 \%$ & $40 \%$ & $40 \%$ \\
\hline 1993 & $20 \%$ & $20 \%$ & $10 \%$ & $10 \%$ & $40 \%$ & $40 \%$ \\
\hline 1994 & $20 \%$ & $20 \%$ & $10 \%$ & $10 \%$ & $36 \%$ & $36 \%$ \\
\hline 1995 & $10 \%$ & $10 \%$ & $10 \%$ & $10 \%$ & $18 \%$ & $18 \%$ \\
\hline 1996 & $10 \%$ & $0 \%$ & $10 \%$ & $10 \%$ & $18 \%$ & $10 \%$ \\
\hline 1997 & $10 \%$ & $0 \%$ & $10 \%$ & $10 \%$ & $18 \%$ & $0 \%$ \\
\hline 1998 & $20 \%$ & $0 \%$ & $20 \%$ & $20 \%$ & $18 \%$ & $0 \%$ \\
\hline 1999 & $20 \%$ & $0 \%$ & $20 \%$ & $20 \%$ & $18 \%$ & $0 \%$ \\
\hline 2000 & $20 \%$ & $0 \%$ & $20 \%$ & $20 \%$ & $18 \%$ & $0 \%$ \\
\hline 2001 & $20 \%$ & $0 \%$ & $20 \%$ & $20 \%$ & $18 \%$ & $0 \%$ \\
\hline 2002 & $20 \%$ & $0 \%$ & $20 \%$ & $20 \%$ & $18 \%$ & $0 \%$ \\
\hline 2003 & $20 \%$ & $0 \%$ & $20 \%$ & $20 \%$ & $18 \%$ & $0 \%$ \\
\hline 2004 & $20 \%$ & $0 \%$ & $20 \%$ & $20 \%$ & $16 \%$ & $0 \%$ \\
\hline 2005 & $25 \%$ & $0 \%$ & $20 \%$ & $20 \%$ & $16 \%$ & $0 \%$ \\
\hline 2006 & $25 \%$ & $0 \%$ & $25 \%$ & $25 \%$ & $16 \%$ & $0 \%$ \\
\hline 2006.09 .01 & $25 \%$ & $0 \%$ & $29 \% 0^{5}$ & $14 \%{ }^{6}$ & $20 \%{ }^{4}$ & $4 \%$ \\
\hline 2007 & $25 \%$ & $20 \%$ & $39 \%^{7}$ & $24 \%^{8}$ & $20 \%{ }^{4}$ & $4 \%$ \\
\hline 2008 & $25 \%$ & $20 \%$ & $39 \% 0^{7}$ & $24 \%{ }^{8}$ & $20 \%{ }^{4}$ & $4 \%$ \\
\hline 2009 & $25 \%$ & $20 \%$ & $39 \%^{7}$ & $24 \%^{8}$ & $20 \%{ }^{4}$ & $4 \%$ \\
\hline 2010 & $25 \%$ & $20 \%$ & $39 \%{ }^{7}$ & $24 \%{ }^{8}$ & $19 \%$ & $0 \%$ \\
\hline
\end{tabular}

Source: Tax regulations, authors' calculation

${ }^{1}$ Private persons pay $35 \%$ tax on dividends received if the value of the dividend exceeds $30 \%$ of the equity.

${ }^{2}$ Assuming positive after-tax profit.

${ }^{3}$ For companies listed on the stock exchange.

${ }^{4} 16 \%$ corporate income tax $+4 \%$ solidarity tax. ${ }^{5} 25 \%+4 \%$ health contribution (EHO); not to be paid if investor has already reached the 400.000 HUF limit).
${ }^{6} 10 \%+4 \%$ health contribution (EHO); not to be paid if investor has already reached the 400.000 HUF limit).

${ }^{7} 25 \%+14 \%$ health contribution (EHO); not to be paid if investor has already reached the 400.000 HUF limit).

${ }^{8} 10 \%+14 \%$ health contribution (EHO); not to be paid if investor has already reached the 400.000 HUF limit). 
On the basis of the formula, the amount of capital gain that should be granted to the market actor to supply the same amount of after-tax income as if a dividend of 100 HUF were furnished can be established - or in other words, what the equivalent of a gain on dividend of 100 HUF is. Obviously, any value over 100 indicates a more favorable tax rate for the dividend, and vice versa.

Apart from the starting year of 1990, within the eighteen annual periods of nine years of changes in tax rates observed; in 2006, there were changes twice. The most important change for companies was a reduction in taxes in 1995; with regard to increases, the most recent one which took place in September 2006 should arouse the most vivid memories. For private persons the income tax rates of withholding tax shrank from 1994 to 1996, and then increased from 1998 to September 2006 on several occasions. These changes are examined with respect to how much the different tax rates of the various actors could be exploited with the use of arbitrage.

Since 1996, corporate investors have had clear tax benefits in the form of dividend payments, as the dividends these investors received from other companies are exempt from taxes, while the capital gain is deemed to be a part of the corporate income tax base, and thus subject to payment of corporate income tax. Since 1998, taxation conditions have been changed on several occasions. From 1996 to 2001, stock exchange shares - provided that they were held in capital accounts - exempted private investors from the effects of the capital gains tax. ${ }^{9}$ Therefore, private investors had clear benefits in assuming profit gains during this period. This means that between 1996-2001, the two groups of investors enjoyed not only comparative, but absolute tax advantages in one or in the other tax type. At dividend payment time, institutional investors 'should have' bought, while private investors 'should have' sold.

9 The context described below is described in relation to private investors who hold their investments in capital accounts 
Table 2 Equivalent of a gain on dividend of 100 HUF for various market actors in Hungary, 1990-2010 (in HUF)

\begin{tabular}{|c|c|c|c|}
\hline \multicolumn{4}{|c|}{ Investor group } \\
\hline & \multicolumn{2}{|c|}{ Private } & \multirow{2}{*}{ Company } \\
\hline & Normal & Preferential $^{1}$ & \\
\hline 1990 & 100.00 & 100.00 & 100.00 \\
\hline 1991 & 100.00 & 100.00 & 100.00 \\
\hline 1992 & 112.50 & 112.50 & 100.00 \\
\hline 1993 & 112.50 & 112.50 & 100.00 \\
\hline 1994 & 112.50 & 112.50 & 100.00 \\
\hline 1995 & 100.00 & 100.00 & 100.00 \\
\hline 1996 & 100.00 & 90.00 & 109.76 \\
\hline 1997 & 100.00 & 90.00 & 121.95 \\
\hline 1998 & 100.00 & 80.00 & 121.95 \\
\hline 1999 & 100.00 & 80.00 & 121.95 \\
\hline 2000 & 100.00 & 80.00 & 121.95 \\
\hline 2001 & 100.00 & 80.00 & 121.95 \\
\hline 2002 & 100.00 & 100.00 & 121.95 \\
\hline 2003 & 100.00 & 80.00 & 121.95 \\
\hline 2004 & 100.00 & 80.00 & 119.05 \\
\hline 2005 & 106.67 & 80.00 & 119.05 \\
\hline 2006 & 100.00 & 75.00 & 119.05 \\
\hline 2006.09 .01 & 94.67 & 86.00 & 120.00 \\
\hline 2007 & 81.33 & 95.00 & 120.00 \\
\hline 2008 & 81.33 & 95.00 & 120.00 \\
\hline 2009 & 81.33 & 95.00 & 120.00 \\
\hline 2010 & 81.33 & 95.00 & 123.46 \\
\hline
\end{tabular}

Source: Authors' calculation on the basis of Table 1

${ }^{1}$ When we assume the kind of private investor who is able to exploit the existing tax benefits in relation to both the capital gains tax and tax on dividend - for instance, an investor who holds stock exchange shares in a capital account.

Table 2 illustrates the amount of dividend that offers a relative tax benefit in comparison with capital gains (the equivalent of capital gains) as regards the three examined groups of actors (private investors being subject to general tax rates, private investors eligible for tax benefits and corporate investors). To aid in understanding, the data of Table 2 are also presented in Figure 2. 
Figure 2 Equivalent of a gain on dividend of 100 HUF in Hungary, from 1990 to 2010

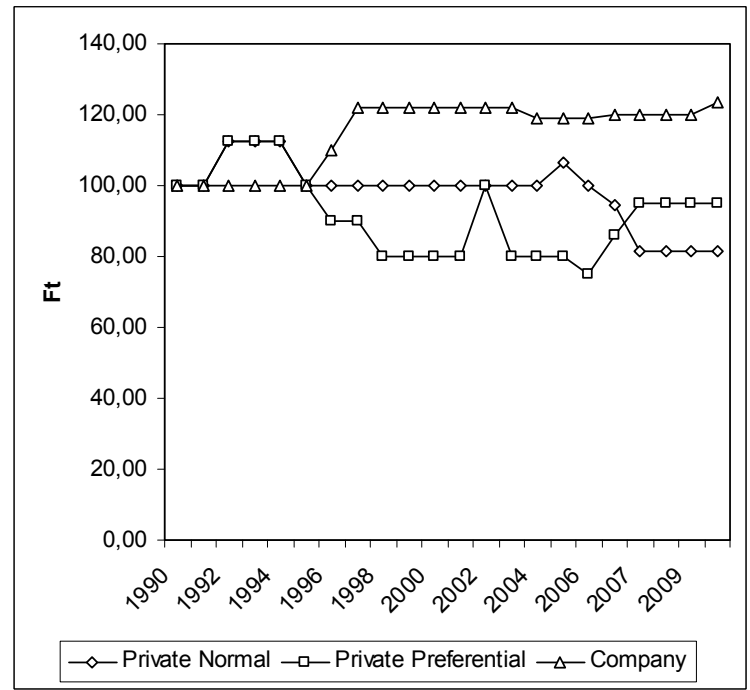

Source: Authors' calculation

The calculation of potential arbitrage is hindered by the fact that any two actors would pay different taxes on capital gains (or save via tax losses). Therefore, tax savings on the capital gains tax can be realized exclusively by corporate actors, and only if they have made losses (prior to dividend payment they make purchases at larger cum-dividend prices, and after dividend payment they sell at smaller ex-dividend prices).

The arbitrage possibilities in connection with the tax on dividend and the capital gains tax are hereby handled separately, and also how prices change within the price range appropriate for arbitrage is examined separately. In between the two extreme values, the value of tax savings is linear, and therefore the calculated values are presented only for these two extreme values.

Savings of the private person in terms of tax on dividend:

$$
D I V * T_{D}
$$

wherein $T_{D}$ is the tax rate on dividend for the private person.

After dividend payment, the minimum price decrease should be such that it makes it worthwhile for the private person to sell the share prior to dividend payment, and repurchase the same after dividend payment: 


$$
D I V^{*}\left(1-T_{D}\right)
$$

After dividend payment, the maximum price decrease should be such that it makes it worthwhile for the corporate actor to purchase the share prior to dividend payment, and sell the same after dividend payment (assuming that the company shows a profit and therefore pays corporate income tax):

$$
D I V /\left(1-T_{C}\right)
$$

On the basis of (9) and (10), the potential price drop range is:

$$
D I V *\left(1-T_{D}\right)<\mathrm{P}_{\mathrm{A}}-\mathrm{P}_{\mathrm{B}}<D I V /\left(1-T_{C}\right)
$$

By using equation 11, a price loss tax savings value can be calculated in connection with the execution of arbitrage positions for a profitable corporate actor (depending on whether the price drop falls to the minimum limit value for the private actor, or the maximum, meaning the limit value for the corporate actor):

$$
D I V *\left(1-T_{D}\right) * T_{C}<P_{A}-P_{B}<D I V /\left(1-T_{C}\right) * T_{C}
$$

By adding up the tax savings of the private actor and corporate actor (that is, the sum of (8) and (9)), the effective range of total tax savings is:

$$
\begin{aligned}
& \text { Minimum: } D I V^{*} T_{D}+D I V^{*}\left(1-T_{D}\right)^{*} T_{C}<P_{A}-P_{B} \\
& \text { Maximum: } P_{A}-P_{B}<D I V^{*} T_{D}+D I V /\left(1-T_{C}\right) * T_{C}
\end{aligned}
$$

For the calculation of potential arbitrage opportunities in detail, see the Appendix. 
Table 3 The amount originating from the payment of a dividend of $100 \mathrm{HUF}$ in arbitrage between companies and private persons, 1990-2010 (in HUF)

\begin{tabular}{|c|c|c|c|c|}
\hline \multirow[b]{2}{*}{ Year } & \multicolumn{2}{|c|}{$\begin{array}{l}\text { Relationship of a private person } \\
\text { with normal tax payment and a } \\
\text { company }\end{array}$} & \multicolumn{2}{|c|}{$\begin{array}{l}\text { Relationship of a private person } \\
\text { with preferential tax payment and } \\
\text { a company }\end{array}$} \\
\hline & Normal & Company & Preferential & Company \\
\hline 1990 & 0.00 & 0.00 & 0.00 & 0.00 \\
\hline 1991 & 0.00 & 0.00 & 0.00 & 0.00 \\
\hline 1992 & 10.00 & 7.50 & 10.00 & 7.50 \\
\hline 1993 & 10.00 & 7.50 & 10.00 & 7.50 \\
\hline 1994 & 10.00 & 8.00 & 10.00 & 8.00 \\
\hline 1995 & 0.00 & 0.00 & 0.00 & 0.00 \\
\hline 1996 & 8.78 & 8.00 & 19.76 & 16.20 \\
\hline 1997 & 19.76 & 18.00 & 31.95 & 26.20 \\
\hline 1998 & 17.56 & 18.00 & 41.95 & 34.40 \\
\hline 1999 & 17.56 & 18.00 & 41.95 & 34.40 \\
\hline 2000 & 17.56 & 18.00 & 41.95 & 34.40 \\
\hline 2001 & 17.56 & 18.00 & 41.95 & 34.40 \\
\hline 2002 & 17.56 & 18.00 & 17.56 & 18.00 \\
\hline 2003 & 17.56 & 18.00 & 41.95 & 34.40 \\
\hline 2004 & 15.24 & 16.00 & 39.05 & 32.80 \\
\hline 2005 & 9.29 & 10.40 & 39.05 & 32.80 \\
\hline 2006 & 14.29 & 16.00 & 44.05 & 37.00 \\
\hline 2006.09 .01 & 19.00 & 20.27 & 34.00 & 27.20 \\
\hline 2007 & 29.00 & 30.93 & 20.00 & 20.00 \\
\hline 2008 & 29.00 & 30.93 & 20.00 & 20.00 \\
\hline 2009 & 29.00 & 30.93 & 20.00 & 20.00 \\
\hline 2010 & 31.59 & 34.12 & 22.77 & 23.05 \\
\hline
\end{tabular}

Source: Authors' own calculations (The data presented in this table indicate the potential volume of profit to be realized, provided that for a given actor, the trading was performed at optimal prices, while the other party generated no profit.)

For each year from 1990 to 2010, the percentage of the dividend (in aggregate earnings) that could be realized by both actors owing to the tax arbitrage positions of corporate and private investors has been calculated. For the individual actors, the above-described capital gain equivalent of the dividend has been established as well. Thereafter, the difference of the capital 
gain equivalent for the two potential partners ${ }^{10}$ has been adjusted for the capital gains tax - using the tax rates for private persons in the first column, and for companies in the second column. The results are presented in Table 3.

To make the data in the table more transparent, two diagrams have been prepared to show the potential range of arbitrage opportunities between a private person who pays taxes on the basis of general tax rates and a corporate investor (Figure 3), and a private person who pays taxes at preferential tax rates and a company (Figure 4).

Figure 3 Arbitrage opportunities between 1990 - 2010 for a dividend of 100 HUF between a private person paying normal taxes and a company (in HUF)

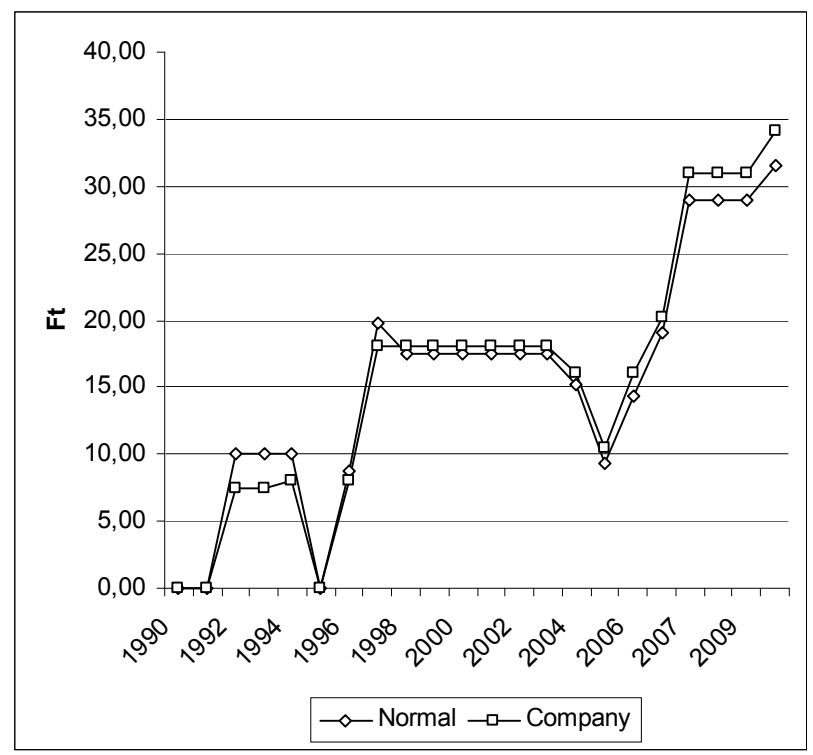

Source: Authors' calculation (The data presented in the figure indicate the potential volume of profit to be realized, provided that for a given actor, the trading was performed at optimal prices, while the other party generated no profit.)

10 The option of arbitrage has been studied only in relation to a company - private person or company - preferred private person (a private person paying taxes at preferential tax rates). The third option, i.e., the private person and private person paying taxes at preferential tax rates, cannot in fact occur within the framework of arbitrage, because the tax benefits are mainly dependent on the given securities - if some benefit has been effected, virtually all the actors rely on the opportunity offered by the capital account. 
As the figure reflects, the years of 1990-91 and 1995 can be regarded as arbitrage-free. It also shows that the objectives of the tax reforms did not focus primarily on the elimination of arbitrage options. Tax reform measures taken in 1995 ruled out the rather moderate arbitrage opportunities that had been in place up to that time. The potential for arbitrage was enhanced by the tax benefits provided to private stakeholders in 1996 (capital gains tax exemption of shares held in security accounts), as well as the exemption of companies from the tax on dividend in effect from 1996, while the changes in September 2006 (for shares traded on the stock exchange, the tax rate on dividend was reduced from $25 \%$ to $10 \%$ ) narrowed their scope (see figure 4 for arbitrage opportunities for private persons with preferential tax rates). If we assume a liquid market (the stock market with its preferential taxes), and that the intense exploitation of arbitrage opportunities is associated mainly with stock exchanges, from September 2006 arbitrage opportunities can be deemed to be moderate. However, the recent changes in 2010 which have seen the cancellation of the extra $4 \%$ corporate tax rate seem to again widen arbitrage possibilities.

Figure 4 Arbitrage opportunities between 1990 - 2010 for a dividend of 100 HUF between a private person paying preferential taxes and a company (in HUF)

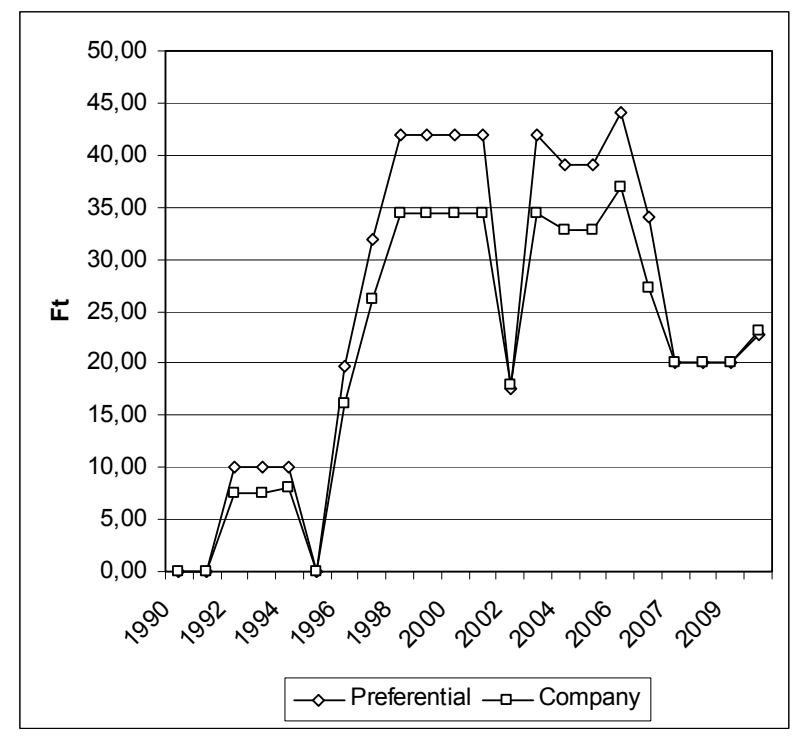

Source: Authors' own calculation (The data presented in the figure indicate the potential volume of profit to be realized, provided that for a given actor, the trading was performed at optimal prices, while the other party generated no profit.) 
Let's assume there are four potential transactions between a private investor and a company (one trading to and from) and altogether they pay a $1 \%$ transaction fee. We can calculate that in 2010:

- A security listed on the stock market (a $23 \%$ gain in arbitrage) should have at least a $(1 / 0.23)=4.4 \%$ dividend yield,

- A security not listed on the stock market (a 34\% gain in arbitrage) should have at least $(1 / 0,34)=3 \%$ dividend yield.

Therefore, the arbitrage situation would be profitable. And there were numerous shares which guaranteed such a high dividend yield.

\subsection{Testing the dynamic tax minimization strategy in Hungary}

For this section we tested to see if investors do try to follow a dynamic tax minimization strategy in Hungary. We wondered if there is extremely high turnover in certain stocks around the dividend payout day - if there is, we assume that greater investor activity means selling or buying a particular stock so as to minimize taxes.

Our portfolio was collected from the Budapest Stock Exchange (BSE) from 1990 - 2007. The panel originally contained 97 stocks - altogether 97 stocks were listed in our stock market in this period.

We used three filters for the sample: one for the period and two for the stocks. In the first years, between 1990 and 1994, we had less stocks and lower turnover - which is why our panel starts only in 1995.

From the stocks we chose only the ones which paid a dividend in the particular year. Evidently, this filter was necessary to test investors' activity around the dividend payment day. The last filter was liquidity - we examined only those stocks which traded at least 100 days in the given year. The t-statistics we used for testing the strategy required certain stability in the turnover - if a stock traded only a few days in a year, the distribution of the turnover and the validity of our test could be called into question. Forty-one stocks remained in the sample. Some of them represent only a single year of activity, and only two stocks, Egis and Richter, are represented for each of the 13 years - the 41 stocks altogether represent 223 pieces of annual data for this period.

In the test we tried to find out if there was abnormal turnover in certain stocks around the dividend payment day. First, for every stock and every year we found the dividend payment day. On the Budapest Stock Exchange one can trade with a dividend coupon until the eighth working day before the 
dividend is paid. Next, we established a five-day and a twenty-day window before and after that day - so altogether for every year we established four testing periods. If during these periods there was abnormal turnover in a given stock, we assumed that the aim of the trade was possibly to implement the tax minimizing strategy. We calculated the logarithm of the turnover for every day for every stock, and calculated the yearly average and standard deviation of the daily turnover for every stock. We assumed that the turnover of the five-day and twenty-day windows and the whole year's turnover come from the same sample, so we used t-statistics to test the abnormal turnovers.

This statistic is for the five-day window (at a 95.5\% significance level):

$$
\bar{x}_{5 \text { days }} \geq \bar{x}_{\text {years }}+2 * \sigma_{5 \text { days }}
$$

This is the statistic for the twenty-day window (at a 95.5\% significance level):

$$
\bar{x}_{20 \text { days }} \geq \bar{x}_{\text {years }}+2 * \sigma_{20 \text { Days }}
$$

Where $\bar{x}$ is the average from the logarithmic data of the turnover,

and $\sigma$ is the standard deviation of the logarithmic data of the daily turnover, calculated for a five-day and a twenty-day period, respectively.

Our hypothesis is that if equation (15) is valid, then there is abnormal turnover in the (+5)-day or (-5)-day window around the dividend payment day, and if equation (16) is valid, then there is abnormal turnover in the $(+/-20)$-day window.

It is quite interesting that the total sample contains 224 pieces of annual data, and from them there was abnormal turnover in 103 cases. If we were to examine four theoretically independent windows at a $95.5 \%$ significance level, theoretically, 16.8 cases out of 100 would show significant turnover ${ }^{11}$. In our sample we have a much higher frequency of abnormal turnover, (103/ $224=46 \%$ ), so almost every second stock showed abnormal turnover around the dividend payment date. In addition, we examined 896 windows (4 X 224), and at a $95.5 \%$ significance level we found 220 cases, almost one-fourth of the total, in which there is abnormal return. So it appears that investors do generate great activity around the dividend payment day.

$\overline{111-0,955^{4}=1-0,832}=0,168$ 
Table 4 Significant turnover by years

\begin{tabular}{|l|c|c|c|c|}
\hline Years & \multicolumn{2}{|c|}{ The whole sample } & \multicolumn{2}{c|}{ Stocks with significant turnover } \\
\hline & $\begin{array}{c}\text { Number of } \\
\text { stocks }\end{array}$ & $\begin{array}{c}\text { Average } \\
\text { dividend yields }\end{array}$ & $\begin{array}{c}\text { Number of } \\
\text { stocks }\end{array}$ & $\begin{array}{c}\text { Average } \\
\text { dividend yields }\end{array}$ \\
\hline 1995 & 13 & $3.26 \%$ & 5 & $4.34 \%$ \\
\hline 1996 & 17 & $2.37 \%$ & 11 & $2.37 \%$ \\
\hline 1997 & 20 & $3.45 \%$ & 16 & $3.14 \%$ \\
\hline 1998 & 19 & $6.84 \%$ & 8 & $5.95 \%$ \\
\hline 1999 & 22 & $6.45 \%$ & 1 & $0.48 \%$ \\
\hline 2000 & 23 & $7.57 \%$ & 5 & $6.32 \%$ \\
\hline 2001 & 21 & $6.09 \%$ & 8 & $6.37 \%$ \\
\hline 2002 & 17 & $7.26 \%$ & 13 & $7.98 \%$ \\
\hline 2003 & 16 & $6.24 \%$ & 13 & $6.39 \%$ \\
\hline 2004 & 15 & $5.36 \%$ & 4 & $5.42 \%$ \\
\hline 2005 & 15 & $3.94 \%$ & 10 & $3.94 \%$ \\
\hline 2006 & 12 & $3.52 \%$ & 8 & $3.92 \%$ \\
\hline 2007 & 14 & $4.59 \%$ & 1 & $9.14 \%$ \\
\hline & 224 & $5.14 \%($ simple $)$ & 103 & $5.06 \%($ simple) \\
\hline Together & & $5.3 \%$ & & $5.02 \%$ \\
& & & weighted) \\
\hline
\end{tabular}

We thought that greater activity would concern stocks with higher dividend yields, but this appears to be false, as this did not apply to the given years, or the given stocks. It appears that there is great activity in those years in which the average dividend yield is not very high (as in 1996, 1997, and 2005).

It is also interesting that the average dividend yield for stocks showing abnormal turnover is a bit lower than the average for the whole sample. So it appears that investors tried to avoid dividend taxation on stocks of both a higher and lower dividend yield. 
Table 5 Statistics on abnormal turnover

\begin{tabular}{|l|c|c|}
\hline & $\begin{array}{c}\text { Number of } \\
\text { annual data }\end{array}$ & $\begin{array}{c}\text { Theoretical } \\
\text { data }\end{array}$ \\
\hline Total sample & 224 & $100 \%$ \\
\hline Showing abnormal turnover in any window & 103 & $16.8 \%=38^{*}$ \\
\hline $\begin{array}{l}\text { Abnormal turnover for both in the five-day and 20-day } \\
\text { window }\end{array}$ & 54 & $0,9^{* *}$ \\
\hline $\begin{array}{l}\text { Abnormal turnover both before and after the dividend } \\
\text { day at least in one window }\end{array}$ & 45 & \\
\hline $\begin{array}{l}\text { Abnormal turnover for both before and after the dividend } \\
\text { day for both in the five-day and twenty-day window }\end{array}$ & 17 & \\
\hline
\end{tabular}

*Assuming that the five-day and twenty-day panels are independent - although it is not true. In assuming independence, the probability is $\operatorname{Pr}=1-(1-0.955)^{4}=0.168$

**Assuming that the five-day and twenty-day panels are independent - although it is not true. In assuming independence, the probability is $\operatorname{Pr}=\left(1-(1-0.955)^{2}\right)^{2}=0.004$

If there is abnormal turnover both before and after the dividend payment day, then it is likely that there is tax arbitrage in the given stock - certain investors buy the stock before the dividend is paid and sell it just after the payment, and other investors sell it before dividend payment and then buy it back afterwards. If the turnover data are independent from each other, then from 224 pieces of data we would have had only 0.9 pieces of data showing higher activity both before and after the dividend payment period - but in fact we have 45 pieces of data. If we look at the other data in Table 5, we recognize even greater arbitrage activity than we would have assumed if the data had related to independent turnover.

We gathered those stocks that were the most interesting ones for investors executing tax-arbitrage transactions. We selected those stocks showing abnormal turnover data of at least five times, and $25 \%$ of the tests. 
Table 6 Stocks showing frequent abnormal turnover

\begin{tabular}{|l|c|c|c|c|c|}
\hline \multirow{2}{*}{ Stock } & \multirow{2}{*}{$\begin{array}{c}\text { Total } \\
\text { years }\end{array}$} & \multicolumn{2}{|c|}{$\begin{array}{c}\text { Years showing } \\
\text { abnormal turnover }\end{array}$} & \multicolumn{2}{c|}{$\begin{array}{c}\text { Total abnormal } \\
\text { turnover in the tests }\end{array}$} \\
\cline { 3 - 6 } & & number & $\%$ & number & $\%$ \\
\hline Borsodchem & 10 & 3 & 30.00 & 12 & 30.00 \\
\hline Brau & 7 & 3 & 42.86 & 7 & 25.00 \\
\hline Dédász & 5 & 2 & 40.00 & 6 & 30.00 \\
\hline Démász & 7 & 4 & 57.14 & 9 & 32.14 \\
\hline Édász & 5 & 2 & 40.00 & 5 & 25.00 \\
\hline Egis & 13 & 8 & 61.54 & 15 & 28.85 \\
\hline Émász & 6 & 4 & 66.67 & 6 & 25.00 \\
\hline Inter-Európa & 10 & 6 & 60.00 & 17 & 42.50 \\
\hline Magyar Telekom & 10 & 7 & 70.00 & 15 & 37.50 \\
\hline MOL & 12 & 7 & 58.33 & 15 & 31.25 \\
\hline OTP & 10 & 4 & 40.00 & 10 & 25.00 \\
\hline Prímagáz & 6 & 4 & 66.67 & 7 & 29.17 \\
\hline Richter & 13 & 6 & 46.15 & 15 & 28.85 \\
\hline Titász & 5 & 2 & 40.00 & 7 & 35.00 \\
\hline Zwack & 12 & 8 & 66.67 & 13 & 27.08 \\
\hline Total & 131 & 70 & 36.59 & 159 & 30.34 \\
\hline
\end{tabular}

From the 41 examined stocks, there were fifteen (37\%) that met the criteria. These fifteen stocks represent 131 years of company data, a bit less than $60 \%$ of the whole sample - 70 years showed abnormal turnover $(68 \%)$ and there were 159 cases $(72 \%)$ from the 220 total significant tests. The fifteen stocks above showed abnormal turnover in more than $50 \%$ of the years on average and in more than $30 \%$ of the tests we conducted.

Some interesting details from the table:

- there was significant turnover in more than two-thirds of the years for the following stocks: Émász, Magyar Telekom, Prímagáz, and Zwack,

- there is significant turnover in more than $40 \%$ of the tests for Inter-Európa Bank stock,

- for the stock of Borsodchem, each test conducted for the significant years 1997, 2002, 2004 turned out to be significant. 
Table 7 Dividend yields of stocks showing abnormal turnover

\begin{tabular}{|l|c|c|c|c|}
\hline Stock & Total years & $\begin{array}{c}\text { Years } \\
\text { showing } \\
\text { abnormal } \\
\text { turnover }\end{array}$ & $\begin{array}{c}\text { Dividend } \\
\text { yield, average } \\
(\%)\end{array}$ & $\begin{array}{c}\text { Dividend } \\
\text { yield during } \\
\text { abnormal } \\
\text { turnover years } \\
(\%)\end{array}$ \\
\hline Borsodchem & 10 & 3 & 5.19 & 3.10 \\
\hline Brau & 7 & 3 & 6.18 & 7.53 \\
\hline Dédász & 5 & 2 & 8.53 & 10.56 \\
\hline Démász & 7 & 4 & 9.08 & 9.01 \\
\hline Édász & 5 & 2 & 9.73 & 8.17 \\
\hline Egis & 13 & 8 & 0.96 & 0.95 \\
\hline Émász & 6 & 4 & 6.48 & 7.17 \\
\hline Inter-Európa & 10 & 6 & 5.35 & 6.10 \\
\hline Magyar Telekom & 10 & 7 & 4.63 & 5.33 \\
\hline MOL & 12 & 7 & 1.39 & 1.24 \\
\hline OTP & 10 & 4 & 1.77 & 1.90 \\
\hline Prímagáz & 6 & 4 & 6.62 & 7.86 \\
\hline Richter & 13 & 6 & 1.70 & 1.84 \\
\hline Titász & 5 & 2 & 8.89 & 9.07 \\
\hline Zwack & 12 & 8 & 8.41 & 8.00 \\
\hline Total & 131 & 70 & 5.14 & 4.72 \\
\hline & & & 5.96 (simple) & $\begin{array}{c}5.50 \\
(\text { simple) }\end{array}$ \\
\hline
\end{tabular}

It is interesting to note that the average dividend yield of the shares in the years with abnormal turnover is not higher than the average dividend yield in the whole sample (the dividend yield for the whole sample was $5.14 \%$, using a weighted method, and $5.32 \%$ using a simple average; for the fifteen stocks and for the significant years these data are $5.14 \%$ and $5.96 \%$, respectively.) But there is a significant difference between the total average of the dividend yield for these fifteen stocks, and the average dividend yield for just the significant years. So it appears that investors mostly used the possibility of arbitrage in those years in which the dividend yield was higher for the given stocks.

It is also interesting to examine in what years we had the most frequent significant turnover. 
Table 8 Connection between tax-keys, dividend yields and abnormal turnover, 1995-2007 (\%)

\begin{tabular}{|c|c|c|c|c|}
\hline & $\begin{array}{c}\text { Potential } \\
\text { arbitrage of } \\
\text { a 100 HUF } \\
\text { dividend* }\end{array}$ & $\begin{array}{c}\text { Percentage of } \\
\text { stocks showing } \\
\text { abnormal return }\end{array}$ & $\begin{array}{c}\text { Average } \\
\text { dividend yield } \\
\text { for all stocks }\end{array}$ & $\begin{array}{c}\text { Average } \\
\text { dividend yield } \\
\text { for stocks } \\
\text { showing } \\
\text { abnormal } \\
\text { turnover }\end{array}$ \\
\hline 1995 & 0.00 & 38.46 & 3.26 & 4,34 \\
\hline 1996 & 19.76 & 64.71 & 2.37 & 2,37 \\
\hline 1997 & 31.95 & 80.00 & 3.45 & 3,14 \\
\hline 1998 & 41.95 & 42.11 & 6.84 & 5,95 \\
\hline 1999 & 41.95 & 4.55 & 6.45 & 0,48 \\
\hline 2000 & 41.95 & 21.74 & 7.42 & 6,32 \\
\hline 2001 & 41.95 & 38.10 & 6.09 & 6,37 \\
\hline 2002 & 17.56 & 76.47 & 7.26 & 7,98 \\
\hline 2003 & 41.95 & 81.25 & 6.24 & 6,39 \\
\hline 2004 & 39.05 & 26.67 & 5.36 & 5,42 \\
\hline 2005 & 39.05 & 73.33 & 3.94 & 3,94 \\
\hline 2006 & 44.05 & 66.67 & 3.52 & 3,92 \\
\hline 2007 & 20.00 & 7.14 & 4.59 & 9,14 \\
\hline $\begin{array}{c}\text { Correlation with the potential } \\
\text { arbitrage }\end{array}$ & -0.019 & +0.415 & +0.008 \\
\hline
\end{tabular}

* Relationship between a private person receiving preferential tax payment and a company - the potential volume of profit is realized by the private person, while the company generates no profit.

In examining Table 8, we can observe that there is no statistical correlation between the tax possibilities and the ratio of stocks showing abnormal turnover in the given year. So it appears that tax arbitrage exists every year, as investors try to use arbitrage opportunities every year, without regard to the cost of the tax deduction. This hypothesis is even stronger if we examine the lack of correlation between the average dividend yield of the chosen stocks and the arbitrage opportunities.

The only apparent connection we could find is between the average dividend yield and the arbitrage opportunity for the given year (Linear correlation $=$ $+0.415)$. It appears that in years in which tax rules provide greater arbitrage opportunities, firms pay a higher dividend yield for the benefit of arbitrageur investors. 


\section{APPENDIX}

In 1998, the tax rate on dividend for private persons increased from ten to twenty percent, and tax arbitrage between private investors and institutional investors promised the largest potential gains between 1998 and 2001 - this period did not see changes in the relevant tax rates. These tax rates have been used for the calculation of the potential aggregate gains of the actors from arbitrage, again assuming that the share price prior to the dividend payment is 1,000 HUF, while the dividend to be paid is 100 HUF.

To calculate the total value of arbitrage, it has also been assumed that a Hungarian private investor sells his stock-exchange share to a Hungarian company somewhere between 1998 and 2001.

The tax rates in effect in that period:

Corporate investor $(C): T_{G C}=T_{C}{ }^{12}=18 \%, T_{D C}=0 \%$;

Private person $(P): T_{G P}=0 \%, T_{D P}=20 \%$.

Tax savings due to the dividend (8): $D I V * T_{D P}=100 \mathrm{HUF}^{*} 0.2=20 \mathrm{HUF}$

Minimum of the potential price drop (9): $D I V *\left(1-T_{D P}\right)=100$ HUF $* 0.8=80$ HUF (meaning that the price can drop down to 920 HUF)

Associated tax savings: $D I V *\left(1-T_{D P}\right) * T_{C}=100 \mathrm{HUF} * 0.8 * 0.18=14.4 \mathrm{HUF}$

Maximum of the potential price drop (10): $D I V /\left(1-T_{C}\right)=100 \mathrm{HUF} / 0.82=121.95$ HUF (meaning that the price can drop down to 878.05 HUF)

Associated tax savings: $D I V /\left(1-T_{C}\right) * T_{C}=100 \mathrm{HUF} / 0.82 * 0.18=21.95 \mathrm{HUF}$

Total tax savings:

Minimum (13): $D I V^{*} T_{D P}+D I V^{*}\left(1-T_{D P}\right) * T_{C}=$ $100 \mathrm{HUF} * 0.2+100 \mathrm{HUF} * 0.8 * 0.18=34.4 \mathrm{HUF}$

Maximum (14): $D I V * T_{D P}+D I V /\left(1-T_{C}\right)=100 \mathrm{HUF} * 0.2+100 \mathrm{HUF} / 0.82=$ $41.95 \mathrm{HUF}$

The total tax savings due to arbitrage could potentially range from $34.4 \%$ to $41.95 \%$ of the paid dividend.

$12 \mathrm{~T}_{\mathrm{C}}$ : Corporate income tax rate 
(Note that the relatively large value of tax savings is explained by the fact that both actors could execute efficient arbitrage at a very high price range: on the basis of the above example, in the ex-dividend price range from 878.05 HUF to $920 \mathrm{HUF}$ at an initial share price of $1.000 \mathrm{HUF}$ and a 100 HUF dividend payment. If in relation to the purchase price, both actors are to settle $0.25 \%$ transaction costs for selling and buying (1\% in aggregate), and transaction prices ensuring maximal ( $41.95 \%$ of the dividend) gains are assumed, then the actors can effectuate arbitrage for shares of dividend yields of $2.38 \%(0.01 / 0.4195)$ in aggregate. $)$

\section{REFERENCES}

Allen, Franklin - Michaely, Roni. (2002), Payout Policy, Wharton School Center for Financial Institutions, University of Pennsylvania.

Blume, Marshall E. - Crockett, Jean - Friend, Irwin (1974), Stock Ownership in the United States: Characteristics and Trends. Survey of Current Business.

Brennan, Michael J. (1970), Taxes, Market Valuation and Corporate Financial Policy. National Tax Journal. December, 417-427.

Dahlquist, Magnus - Robertsson, Göran - Rydqvist, Kristian (2007), Direct Evidence on Dividend Tax Clienteles, CEPR Discussion Papers 6005.

Elton, Edwin J. - Gruber, Martin J. (1970), Marginal Stockholder Tax Rates and the Clientele Effect. The Review of Economics and Statistics, Vol. 1, 68-74.

Fazakas Gergely-Kosárka Judit(2008), Azadók hatása azosztalékpolitikára, (Tax effects on Dividend Policy) Közgazdasági Szemle, szeptember, 782806.

Graham, John - Kumar, Alok (2005) Do Dividend Clienteles Exist? Evidence on Dividend Peferences of Retail Investors. The Journal of Finance, 2005, 1305-1336.

Jaksity György (1991), Az osztalékpolitika és a részvényárfolyamok. (The dividend policy and stock prices) Pénzügyi Szemle, 390-415.

Kalay, Avner (1982), The Ex-Dividend Day Behavior of Stock Prices: A Re-Examination of the Clientele Effect, The Journal of Finance, 1059-1070.

Kosárka Judit (2007), Az adó hatása az osztalékpolitikára (Tax effects on Dividend Policy), Thesis, BCE.

Litzenberger, Robert. H. - Ramaswamy, Krisna. R. (1980), Dividends, Short Selling Restrictions, Tax-Induced Investor Clienteles and Market Equilibrium, The Journal of Finance, May, 469-482. 
Litzenberger, Robert. H. - Ramaswamy, Krisna. (1982), The Effects of Dividends on Common Stock Prices. Tax Effects or Information Effects? The Journal of Finance, May, 429-443.

Long, John B. (1977), Efficient Portfolio Choice with Differential Taxation of Dividends and Capital Gains. Journal of Financial Economics.

Michaely, Robert - Vila, Jean-Luc (1996) Trading volume with private valuation: evidence from the ex-dividend day. Review of Financial Economics, $471-509$.

Michaely, Robert - Vila, Jean-Luc - Wang, Jiang (1997), A model of trading volume with tax-induced heterogeneous valuation and transaction costs, Journal of Financial Intermediation, Vol. 5, 340 - 371.

Poterba, James - Summers, Lawrence H. (1984), New Evidence that Taxes Affect the Valuation of Dividends, Journal of Finance, 1397-1415. 